\title{
Marketing Islamic services: tackling misconceptualisation of commercial insurance
}

\author{
Djavlonbek Kadirov \\ Victoria Business School, School of Marketing and International Business, \\ Victoria University of Wellington, Wellington, New Zealand
}

Marketing Islamic services

Received 28 August 2019 Revised 28 December 2019 23 January 2020 Accepted 24 January 2020

\begin{abstract}
Purpose - The purpose of this paper is to offer an alternative conceptualisation of commercial insurance that is based on service thinking and compares it to the ideas flowing from goods thinking that currently appears to be a dominant mindset.

Design/methodology/approach - When deliberating on commercial insurance, Muslim jurists and scholars followed a misleading route of logical reasoning that is based on comparing insurance to other approved commercial contracts within Islamic Law. In this paper, the author questions such reasoning by contrasting the framework of service thinking to that of goods thinking.

Findings - The alternative framework proposed in this paper repositions commercial insurance as a unique type of service (rather than a good). It shows that commercial insurance can be seen as a bundle of benefits, which unfold in a gradual, intermittent, sporadic manner depending on the circumstances. This mode of a servicing relationship focuses on harm removal rather than the opportunistic actualisation of unfair monetary gain. Insurance premium is conceptualised as an availability fee, while compensation payout is recast as the restoration of value.

Practical implications - Muslim jurists and marketing practitioners can use this framework to further scrutinise the permissibility of different varieties of commercial insurance in the contexts of both Muslim and non-Muslim majority countries. As service thinking radically repositions the essence and structure of commercial insurance, the views on the relevance of "gharar" and "riba" may undergo significant reconceptualisation. Moreover, the design of takaful options can be improved on this basis.

Social implications - Service thinking can better elucidate a positive societal role of commercial insurance that is in accord with the societal and Islamic maxim of harm removal. Some objections to commercial insurance relate to public policy failures. Well-regulated commercial insurance industries can substantially contribute to the economic development of impoverished societies.

Originality/value - This paper exemplifies compelling power as well as potential of the discipline of Islamic marketing in contributing to significant debates concerning the permissibility of modern commercial options.
\end{abstract}

Keywords Islamic finance, Insurance, Takaful, Commercial insurance, Goods thinking,

Service thinking

Paper type Conceptual paper

\section{Introduction}

Islam strongly emphasises harm prevention including the protection of one's life, reputation and property. The notion of ta'min (e.g. insurance) as a general concept of ensuring wellbeing in this world and the hereafter is deeply ingrained in daily prayers and practices of Muslims (Khorshid, 2004). However, if one seeks an advice about the legal permissibility of conventional insurance from the Islamic perspective, in general, the news is not positive. Although there are various approaches and perspectives of conceptualising insurance, most Muslim jurists and scholars reject conventional insurance on the basis of insurance 
contracts containing riba (unjustified earning), gharar (uncertainty) and maysir (gambling) (Khorshid, 2004). Although the contemporary insurance industry offers workable solutions to manage various types of risk in both personal and commercial contexts, most of these solutions are rejected by Muslim scholars as non-Islamic. The topic of insurance is extremely important for Muslim markets. Many international conferences and fatwa councils such as the Second Islamic Jurisprudence Convention (held in Damascus in 1961), Islamic Research Institution Conferences (held in Cairo in 1965, 1966), First Symposium on Islamic Jurisprudence (held in Libya in 1972), First Conference on Islamic Economics (1976), the Higher Council of Saudi Ulemas and the Islamic Fiqh Academy deliberated on the issue. These councils largely supported mutual, cooperative and collective schemes, while criticising commercial insurance. In contrast, in 1961 Sheikh Ali Al-Khafif presented his detailed research on commercial insurance at the second conference of the Islamic Research Forum (Cairo), where he declared it as a positive system of humanistic cooperation that is a fundamental necessity to maintain social stability (Khorshid, 2004).

On a global scale, commercial insurance is an important services sector. In recent years, the overall volume of premiums reached $€ 4.7 \mathrm{tn}$ worldwide, while the industry grew at an average annual pace of four per cent (McKinsey and Company, 2019). The major sectors in the industry are life insurance, which makes up 46 per cent of global insurance premiums, health insurance (23 per cent) and property and casualty insurance (30 per cent). Health insurance appears to be the fastest growing sector whereby the growth rate being 5.1 per cent (McKinsey and Company, 2019). In recent years, the developing The Asia Pacific Accreditation Cooperation countries (namely, China, India, Indonesia, Malaysia, Philippines, Thailand and Vietnam) accounted for a whopping share of total growth in the industry, which is 31 per cent, while the Middle-East countries (Bahrain, Iran, Israel, Jordan, Saudi Arabia, Turkey and UAE) registered a merely 3 per cent share of total growth. The Organization for Economic Co-operation and Development (OECD) data shows that while countries like Russia show strong growth rates in both life and non-life insurance (29.9 and 3.5 per cent, respectively), Turkey faced a shrinking market $(-2.9$ and -5.8 per cent, respectively) (OECD, 2019). In the countries with significant Muslim population, Islamic alternatives to commercial insurance (e.g. takaful) are gradually emerging. The takaful market currently operates in 45 countries, and its size is estimated to be at about US\$46bn (Al-Natoor, 2019). Some of the significant industry players in this market are Islamic Insurance Company, JamaPunji, AMAN, Salama, Standard Chartered, Takaful Brunei Darussalam Sdn Bhd, Allianz, Prudential BSN Takaful Berhad, Zurich Malaysia, Takaful Malaysia and Qatar Islamic Insurance Company. However, takaful failed to fully replace other types of insurance in most Islamic markets. For example, in UAE, takaful accounts for only 15 per cent of gross written premiums (Al-Natoor, 2019). As the practicality of the ideal Islamic insurance principles is constantly questioned, most commentators and practitioners still see takaful as the "second best" option (Sadeghi, 2010). The reason could be that conventional insurance companies appear to outperform takaful insurance schemes in terms of efficiency (Antonio et al., 2013). Also, there are concerns that takaful has become a play of semantics, i.e. offering the same conventional service camouflaged under the complex set of Islamic finance terminology (Moghaizel, 1991; Nahar, 2015). Nevertheless, the author fully supports the development of communal, mutual or public insurance schemes based on takaful principles that are truly effective and help communities and individuals achieve their goals. However, in this paper, the author invites the readers to join in the "what if" conceptual exercise and ask whether by absolutely rejecting current commercial insurance solutions, decision makers (e.g. scholars, practitioners and public policymakers) are not "throwing the baby out with the bathwater". For instance, Bekkin (2007) argued that 
commercial insurance should be considered as fasid (defective) rather than batil (invalid), which would enable and also encourage market actors to work to correct its shortcomings.

Muslim jurists need to distinguish between exchanges that involve goods (tangible objects such as fruits) versus services (intangible benefits such as guarding a house). Insurance definitely is a service, while the problem is that most opinions and rulings treat it as a "good". In this paper, the author's aim is to offer an alternative conceptualisation of commercial insurance based on service thinking in contrast to goods thinking that currently appears to be a dominant mindset. To do this, a brief historical overview of the development of insurance and a summary of the current debates on insurance from the Islamic legal perspective are presented. Then, service thinking as an alternative way of logical reasoning about commercial exchanges and its comparison to goods thinking are discussed. This will be followed by the discussion of an alternative service framework of commercial insurance, which radically repositions commercial insurance as a viable Islamic mode of service provisioning. The conclusion section wraps up the discussion by summarising the main points and indicating potential implications.

\section{Historical roots of commercial insurance}

Islam emphasises protection from harm, dispute and uncertainty (Al-Qaradawi, 1994). While traditional economic thought focuses on economic growth, Islamic commercial thought strongly emphasises harm prevention. Throughout the centuries, Muslim jurists stressed the importance of harm prevention in economic activities to protect individuals, communities, society at large and the natural ecosystems. This is reflected in the goals of Sacred Law (Shariah) driven to protect five necessities: religion, life, intellect, future generations and property (Auda, 2008). Islamic jurisprudence defines anything that endangers these five necessities as "harm". The legal maxims state that harm must be removed or eliminated (ad-darar yuzal) and that no harm shall be incited or reciprocated (la darar wa la dirar) (Zakariyah, 2015). In principle, echoing the spirit of harm prevention, insurance represents an institutional mechanism directed at reducing the negative impact of a specific risk on an individual by distributing its effect over a broader group of mutually cooperating individuals (Al-Qaradawi, 1994; Bekkin, 2007; Khorshid, 2004). Commercial insurance can be seen as one of the ways of bringing different individuals, households and organisations with varying interests together to deal with identified risks deemed to be crucial for a specific market or consumption activity.

Historically, various local insurance solutions emerged as a way of dealing with potential harm from unpredictable events (e.g. loss of life, health or property because of natural disasters such as storm, fire or other uncontrollable calamities). In general, living in closely intertwined communities where individuals and households can get mutual support and community aid in emergency situations was a kind of insurance arrangement. However, as societies became more commercialised, people found themselves to be in need of specialised institutions that could help with risk management. It is known that Chinese and Babylonians established the earliest version of insurance schemes in the 3rd millennium BC (Vaughan, 1996). For example, public granaries played an important role of circumventing hunger during famines. In the middle ages, most trade was conducted through the sea via sea-faring vessels or deserts via caravans, where goods were subject to a number of risks such as piracy, fire, storms or confiscation by rival countries. Merchants used different ways to deal with the risk: high-per cent loans, fictitious insurance-like loans, use of multiple agents in different ports and small lot trading (Kingston, 2014). By the fourteenth century, advanced contracts of marine insurance became very common (Go, 2009; Kingston, 2014). Insurance markets flourished in Venice, Amsterdam and London. During the eighteenth
Marketing Islamic services 
century Lloyd's of London coffeehouse emerged as a centre of marine insurance attracting merchants from different parts of the world (Kingston, 2014). Insurance underwriters with established reputation, trust, competitiveness and impartial arbitration were particularly valued by merchants. Similarly, nearly about the same time property insurance institutions developed as a way of tackling property damage by frequent fires in London (Vaughan, 1996).

Muslim jurist Ibn Abidin's (1784, 1836) commentary on insurance (Khorshid, 2004; Tolefat and Asutay, 2013) shows that Muslim traders used to practice a type of marine insurance called "sowkra". Sowkra involved a non-Muslim agent who had the governor's permission to collect sowkra payments from merchants for a merchandise to be sent by a boat. If anything happened to the merchandise at the sea, this agent would cover the full cost of the damage. Ibn Abidin considered such a contract corrupt as this contract involved a guarantee of something that is unknown or impossible to control (Khorshid, 2004). Ibn Abidin's argument involved a comparison of sowkra to different Islamic contracts:

- the deposit contract (the depositee can charge the depositor a fee for his/her services);

- bailment (al-kafalah); and

- the guarantee contract, dhaman khataral tariq (the guarantor can charge a fee to ensure the safety of a traveller) (Tolefat and Asutay, 2013).

Ibn Abidin argued, that since sowkra is not similar to these contracts, it is deemed illegal. Only when the insurance contract is done in a non-Muslim territory or two non-Muslims are involved in the contract (one of them as a partner of a Muslim merchant), only then, according to Ibn Abidin, the insurance compensation for the loss incurred should be allowed.

It is known that Sheikh Mohamed Bukhit, the mufti of Egypt, supported Ibn Abidin's opinion of the impermissibility of insurance (Tolefat and Asutay, 2013). In contrast, Sheikh Muhammad Abdu (an Egyptian scholar) approved life insurance as a kind of mudaraba (i.e. a profit-sharing investment-based contract) in 1901 (Khorshid, 2004). Although some jurists supported this opinion, many others rejected this comparison. They argued that life insurance contracts, unlike mudaraba, do not affirm the likelihood of loss and the accompanying responsibility of sharing it proportionally. Moreover, they argued that abruptly ceasing contracts whereby all instalments would not be paid creates a situation that resembles gambling. An extended debate ensued in Islamic legal circles on whether insurance resembles mudaraba, some details of which are extensively discussed in Khorshid (2004). It is out of scope of this paper to delve into the minute details of the debate. It must be noted that some scholars such as Ahmed Taha el-Sanousi discussed insurance (Al-Azhar Magazine, Vol. 25, Part 2: 23) as a unique type of contract that does not resemble any other types of Islamically approved contracts such as mudaraba or musharaka.

\section{Current debates on commercial insurance}

The permissibility of insurance from the perspective of Islamic law is a widely debated issue. Researchers classified arguments into several groups. Based on Khorshid (2004) and Tolefat and Asutay (2013), one can distinguish the following approaches: absolutist, circumstantial and exception-based. The absolutist approach is based on either total approval or total rejection of all types of insurance. The circumstantial approach considers all insurance contracts to be corrupt, whereas maintaining that the extreme cases of necessity may make some of insurance variants permissible. The exception-based approach 
is based on affirming different exceptions to the general rule: some scholars reject all types of insurance except indemnity insurance (e.g. motor insurance), while some others think all insurance is invalid except insurance that is based on communal or cooperative partnership. Another group of scholars approve all types of insurance except life insurance.

At the heart of the commercial insurance debate is the relevance of uncertainty (gharar in Islamic legal jargon) based prohibition. Most scholars either reject or accept a typical commercial insurance contract based on their judgment of the possibility of gharar (Kamali, 2000; Khorshid, 2004; Tolefat and Asutay, 2013). Gharar exists when the seller or the buyer are not certain about whether the product value will actualise after the transaction (i.e. if one sells a camel on the loose, there is no certainty whether the buyer can actually catch it to be able to use it). In general, gharar "comprises uncertainty and risk-taking as well as excessive speculation, gambling and ignorance of the material aspects of contracts" (Kamali, 2000, p. 96). It is commonly accepted that the criteria of assessment are such that the rule of gharar only applies to a contract when:

- gharar is deemed excessive (not light);

- the contract is muawadah (commercial exchange) and it is not tabarru (donation);

- gharar affects the main elements of the contract (e.g. price, value and time); and

- the contract is not driven by necessity, i.e. other alternatives are available (Tolefat and Asutay, 2013).

Muslim jurists who rejected commercial insurance argued that gharar in commercial insurance satisfies all these criteria. Gharar in insurance is deemed to be excessive because it involves the following types of uncertainty:

- uncertainty regarding the outcome of the contract (will the risk occur at all?);

- uncertainty regarding a total sum of premiums;

- uncertainty regarding a total sum of a compensation payment; and

- uncertainty regarding the contract period (Tolefat and Asutay, 2013).

They also think that commercial insurance contracts are muawadah, i.e. a commercial transaction where counter-values are exchanged. Moreover, they argued that in addition to a commercial insurance's "product" and "price" being uncertain, people are not critically dependent on such contracts as alternatives now exist in the form of takaful contracts. In addition, some scholars explored the impact of riba, i.e. the element of interest in insurance contracts. Some of them compared insurance to money exchange (sarf) contracts, where premiums are exchanged for a compensation (Muslehuddin, 1966; Khorshid, 2004). Since these two sums were not equal, they argued that insurance may involve riba, which would invalidate insurance. Moreover, some scholars thought that the customer's premium is a maysir (gambling) payment akin to betting in the context of gambling. If the risk occurred, then the customer would receive a payout, whereas if it did not occur, then the customer would lose. Hence, these scholars prohibited insurance because of its structural similarity to gambling.

A group of Muslim jurists and thinkers (e.g. scholars such as Al-Zarqa, Al-Khafif, Siddiqi) defend the case of conventional commercial insurance by refuting the aforementioned claims (Khorshid, 2004; Tolefat and Asutay, 2013). They indicate a logical contradiction contending that gharar must apply to takaful contracts and mutual/public schemes in the same way it applies to commercial insurance, since the use of the "donation" scheme does not change the contract's essence (Moghaizel, 1991). They argue that functional 
contingency in approved public/state insurance schemes is at the same level as in the contracts of commercial insurance, hence differences between these options are not clearly justified. Moreover, these scholars argue that commercial insurance is not a typical sell-buy contract (Khorshid, 2004). Rather, it appears to be a unique type of service based on mutual cooperation, pooled resources and collective support. These elements are seen as comparable to those of legitimised mutually cooperative schemes. Another line of argument supporting commercial insurance focuses on the notion of "benefit": since both parties (the insurer and the insured) benefit from the contract, gharar is deemed non-excessive. Accordingly, there is a fine balance between counter-benefits exchanged: the insurer receives premium, while the insured receives either "peace of mind" or compensation. Furthermore, these scholars argue that uncertainty arises at the individual level only. It is noted that on the collective level there exist reliable ways of estimating the risk:

[... . matters are known and certain at the collective level, though unknown and uncertain at the individual level. It would not be proper to ignore the collective nature of insurance and to prohibit it on the ground of gharar present at the individual level (Siddiqi, 1985, p. 42).

Last but not the least, arguments for commercial insurance raise the issue of harm related to the prevention of future dispute. Since government regulation, industry standards and thoroughly written contracts offered by reputable businesses significantly reduce the possibility of future dispute, the Islamic maxim of securing benefit and preventing harm appears to be satisfied through such contracts (Tolefat and Asutay, 2013).

To summarise, the debate on the legal permissibility of conventional commercial insurance is still ongoing. A variety of arguments and counterarguments are used to either affirm or reject the case of commercial insurance. This state of conceptual uncertainty adds to the frustration of many market thinkers, marketing practitioners and policy makers. Moreover, this uncertainty poses a substantial barrier for investment and development in impoverished societies, which face extremely high levels of both commercial and noncommercial risk.

Criticising the predominant method of logical reasoning, Khorshid (2004, p. 25) commented:

To reiterate, it would appear that methods which merely study the validity of new contracts and attempt to fit them forcibly into nominate Islamic contracts spring from a prejudiced view of the Shari'a and have been proven to be unwarranted. A more appropriate route to follow is to make use of the contractual freedom afforded by Islamic law, rather than insisting on an obsolete scheme of basic nominate transactions, acknowledged, at the time they were devised and recognized by the Shari'a, as highly sophisticated and able to serve the needs of that time. As far as insurance is concerned, it is obvious that as a concept it does not correspond to any of the nominate contracts of Islamic law and, more importantly, it cannot be adapted to fit these, whatever modifications are devised, without being deprived of its major features.

There appears to be a strong need for alternative conceptualisations to resolve the issue. To address this issue to some extent, this paper offers a potentially promising route of reasoning based on service thinking (Vargo and Lusch, 2004). Such reasoning is a unique contribution of the marketing discipline, hence Islamic marketing is considered to be the best avenue of introducing this framework into insurance debates in the Muslim markets.

\section{Service thinking versus goods thinking}

The overview of the existing views on commercial insurance indicates that Muslim jurists and scholars were mostly involved in comparative analysis of different contract types. Although Islamic jurisprudence is open to a wide variety of contract models, the classical 
view of quid pro quo exchange, the act of giving up a thing of value for another thing of value (e.g. in some cases money) in return, is accepted as default. All other cases are considered as an exception to this default mode. It is shown that the closest contract mode to the notion of service in Islamic legal thought is ijarah (i.e. lease). Ijarah is considered to be the sale of benefits. From the perspective of Islamic law, ijarah is allowed as an exception, because it involves the sale of an intangible and uncertain value, which is contrary to the general premise of impermissibility of selling non-existent "things". Since ijarah is treated as an exception, all other types of pure services (e.g. counselling, maintenance, subscription services, software and IT contracts and computing) must be individually justified as either falling under ijarah or other relevant contracts (e.g. hire and security). The legal practice of referencing the default, looking for equivalent contracts, comparisons and logical extensions appears to be an exhausting exercise. Moreover, the key debates appear to be never ending, while at the same time creating significant barriers for business practitioners who would prefer straightforward solutions. In general, this paper argues that the classic view of exchange represents goods thinking that has substantial limitations when applied to complex cases of service provision.

Service thinking is essentially encapsulated in the service dominant logic (Vargo and Lusch, 2004). From the service dominant logic perspective, service is not seen as an opposite of a tangible good, rather it is seen as the broad concept that encompasses all types of goods (tangible as well as intangible goods, events, ideas, places, personalities and experiences) in markets. Service is defined as "applying specialized competences (knowledge and skills) through deeds, processes, and performances for the benefit of another actor or the actor itself" (Lusch and Nambisan, 2015, p. 158). A tangible product, for example a car, represents a service in a sense that it offers a bundle of benefits that the buyer can potentially use.

The main point in service thinking is the precept that declares that market relationships based on service provision do not involve an exchange of "things". Rather, these relationships involve the application of ongoing processes of benefit creation. Accordingly, the insured's benefits are not received in one go, i.e. as a single batch "dispatched" by the insurer. The benefit gradually unfolds, progresses, evolves and actualises as time goes. Although some may see uncertainty in how these processes would be operationalised by the provider, the essence and outcome of this kind of service provision would be well defined $a$ priori. Furthermore, service providers and service receivers are considered as the integrators of resources. The price of the service is considered as a compensation for the superior process of integrating resources that delivers sustaining benefits. This is in contrast to the goods thinking assumption that takes the price as a counter-value paid for the delivery of a "tangible thing".

\section{Theory of commercial insurance-as-service}

Commercial insurance should be considered as a type of service. The conceptualisation of the key characteristics of this type of service is given in Table I. In the Table, to better elucidate the differences, the proposed characteristics are conceptually juxtaposed against the conventionally accepted assumptions about commercial insurance from the goods perspective.

\section{Essence of commercial insurance}

Goods thinking involve a view of commercial insurance as a good, that is, a chunk of value that is produced and delivered by the insurer in exchange for a payment by the insured. This is reflected in the opinion of Islamic scholars on muawadah (commutative contract) versus tabarrat (gratuitous contract) dealings (Tolefat and Asutay, 2013). Most scholars 


\begin{tabular}{|c|c|c|c|}
\hline \multirow[t]{3}{*}{ JIMA } & Criteria & "Goods" conceptualisation & "Service" conceptualisation \\
\hline & Essence & $\begin{array}{l}\text { Insurance is a good, i.e. a chunk of value } \\
\text { to be produced and delivered in exchange } \\
\text { for a payment }\end{array}$ & $\begin{array}{l}\text { Insurance is a service, i.e. a bundle of } \\
\text { benefits that can be potentially used in a } \\
\text { gradual, intermittent, sporadic manner } \\
\text { depending on circumstances }\end{array}$ \\
\hline & Form & $\begin{array}{l}\text { Transaction: a one-off contract of counter- } \\
\text { value exchange }\end{array}$ & $\begin{array}{l}\text { Relationship: indefinite long-term } \\
\text { cooperation and value creation }\end{array}$ \\
\hline \multirow{5}{*}{$\begin{array}{l}\text { Table I. } \\
\text { Alternative } \\
\text { conceptualisations of } \\
\text { commercial } \\
\text { insurance }\end{array}$} & Key benefit & $\begin{array}{l}\text { Attaining gain: gaining an extra value at } \\
\text { the expense of other insurers }\end{array}$ & $\begin{array}{l}\text { Removal of harm: maintaining the full } \\
\text { value of a focal asset at a specific level } \\
\text { under risk exposure }\end{array}$ \\
\hline & $\begin{array}{l}\text { Insurance } \\
\text { compensation }\end{array}$ & $\begin{array}{l}\text { Payout: receiving unjustified gain at the } \\
\text { expense of someone else's unfair loss }\end{array}$ & $\begin{array}{l}\text { Value restoration: indemnifying the } \\
\text { agreed upon value of a focal asset }\end{array}$ \\
\hline & $\begin{array}{l}\text { Insurance } \\
\text { premium }\end{array}$ & $\begin{array}{l}\text { Gambler's bet: placing a bet with a view } \\
\text { of winning it }\end{array}$ & $\begin{array}{l}\text { Availability fee: a service fee as a } \\
\text { compensation for the insurer's } \\
\text { opportunity cost, i.e. tying up their } \\
\text { resources }\end{array}$ \\
\hline & $\begin{array}{l}\text { Justification of } \\
\text { benefits }\end{array}$ & $\begin{array}{l}\text { Opportunism: the actors are opportunists } \\
\text { taking an advantage of each other }\end{array}$ & $\begin{array}{l}\text { Resource integration: the actors integrate } \\
\text { resources available to them to create } \\
\text { unique value for other and themselves }\end{array}$ \\
\hline & Context & $\begin{array}{l}\text { Dyads: isolated (the insurer versus the } \\
\text { customer) and asymmetric interactions }\end{array}$ & $\begin{array}{l}\text { Network: the insurer as well as customers } \\
\text { are equal resource integrating actors in a } \\
\text { common network }\end{array}$ \\
\hline
\end{tabular}

invalidate insurance because it represents muawadah, an exchange of a value for a countervalue (Al-Salih, 2004; Baltiji, 1987). However, once this perspective is taken, it leads to a conundrum: insurance is seen as a sale of uncertain "promise" (i.e. insurance premium) or alternatively, as the sale of money (i.e. potential premium) for money (i.e. instalments).

In contrast, the service conceptualisation proposes that commercial insurance should be seen as a service, that is, a bundle of benefits that can be potentially used in a gradual, intermittent, sporadic manner depending on circumstances. It must be realised that insurance is neither an exchange of a tangible product for money nor a transaction of lease (ijarah) or hire. Its benefit(s) do not exist at the time of signing the agreement, rather these benefits unfold as one continues his/her membership in the scheme. The extent to which some or any benefits are going to be realised would depend on the customer's actions, one's circumstances and other uncontrollable factors. Most subscription-based services have these features. For example, consider the following analogy. Two customers individually subscribe for an annual gym membership. One of them stops going to gym after a couple of sessions because of personal circumstances arising from an uncontrollable event, while the other one continues to attend while benefiting from the service to a great extent: physically, psychologically and socially. Could one argue that the gym took an unfair advantage of the first customer's circumstance, while the second customer got more than he/she has subscribed for? Because of different levels of benefits accrued, would it be logical to insist that gym membership involves gharar and possibly riba? For most services, promised benefits are potential benefits, which might actualise or unfold in a quite uncertain manner. For example, one might hire a boat but never be able to use it because of unpredictable weather patterns in the sea for that particular period. Similarly, one might subscribe to a content-streaming service and end up watching nothing. This kind of uncertainty concerning the temporal and circumstantial unfolding of benefits does not upset the agreed balance of rights and responsibilities according to the Maliki school of thought and Ibn 
Taymiyya (Khorshid, 2004), hence the application of the concept of gharar might need to be reconsidered. Here, gharar applies to the business as a whole, which is typical of any approved business transaction, rather than its subject matter (Bekkin, 2007; Khorshid, 2004; Tolefat and Asutay, 2013). Even if some gharar exists in its subject matter, it can be approved as part of maslaha mursalah (i.e. the common good) (Tolefat and Asutay, 2013), since not all transactions with severe gharar are prohibited in Islamic jurisprudence (A1Saati, 2003). Scholars must take a systems (macro) view (Auda, 2008), while removing hardship must be the highest priority (Kamali, 2000). Furthermore, functional contingency that involves significant gharar is inherent in many Islamic contracts such as will, guarantee, mudaraba (partnership), ji'ala (reward) and sorat (security agreement) (Khorshid, 2004). Hence, straightjacketing the maxim of gharar on unfamiliar cases with no distinction is questionable.

\section{Form of commercial insurance}

Goods thinking accepts insurance as a one-off transaction where the parties exchange counter-values. However, the actual form of commercial insurance is quite far from a typical transaction: it does not represent a conventional exchange involving money or a barter involving counter values. Neither is it an aggregation of one-off transactions following each other. Commercial insurance in most cases involves an ongoing relationship and it is based on the assumption of indefinite cooperation and mutual value creation to counter the effects of risk. Service thinking emphasises relationship rather than transaction (Grönroos, 1995; Gummesson, 2011). Relations are rarely one-to-one. Gummesson (2011) notes that relationships involve networks - supplier networks working with customer networks on a continuous basis. A customer does not purchase insurance, rather he/she subscribes into a network of similar customers contributing to a common pool of resources, which are managed by the networks of supplying marketing systems. Here, a marketing system would include the insurer, its industry partners, market regulation bodies, associations, local authorities and government (Kadirov, 2014). A defective insurance option (e.g. the issues related to riba, maysir and exploitation) is in fact the failure of the whole marketing system.

The networks, institutions and marketing system must ensure that insurance relationships are based on good faith . Parties enter into a relationship with an expectation that the other party maintains good faith during this relationship. The Maliki school of thought particularly emphasises the fact that gharar invalidates the contract only if it upsets the pre-agreed balance of mutual rights and responsibilities (Khorshid, 2004). Since commercial insurance involves a balanced relationship with clearly defined rights and responsibilities, it may not fall under the category of gharar prohibition. In general, the Islamic conceptualisation of exchanges should take into account the fact that relationshipbased exchanges are radically different to one-off exchanges.

\section{Key benefits of commercial insurance}

The goods perspective focusses on gain accrual, whereas the service perspective focuses on harm prevention (Figure 1). Focussing on the goods nature of the offer, Muslim jurists incorrectly explain the "unit" for sale. For them, what is sold is an opportunity to make an unfair gain that may resemble the context of gambling (Baltiji, 1987; Melhim, 2002; Wahab et al., 2007). In other words, they are overly concerned about the financial dimension of the relationship. For these thinkers, the normality (of no gain when the insured risk fails to materialise) is broken by an unfair gain for the customer who is "lucky" in a sense that the calamity he/she was trying to avoid at the onset actually takes place. Such an argument is not only illogical because it claims that the calamity (risk) is a "gain" but also unfairly 


\section{JIMA}

Figure 1.

Alternative views of commercial insurance

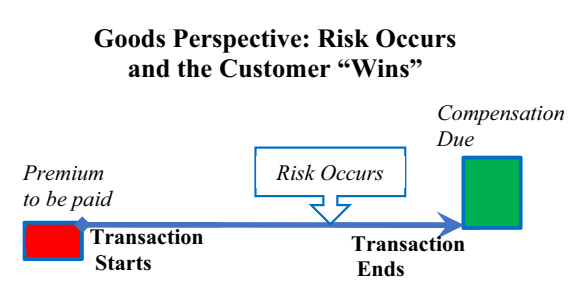

Goods Perspective: Risk Does Not Occur and the Customer "Loses"

\begin{tabular}{|l}
$\begin{array}{l}\text { Premium } \\
\text { to be paid }\end{array}$ \\
\hline $\begin{array}{l}\text { Transaction } \\
\text { Starts }\end{array}$ \\
\hline
\end{tabular}

Service Perspective: Risk Occurs and the Customer Recovers Value

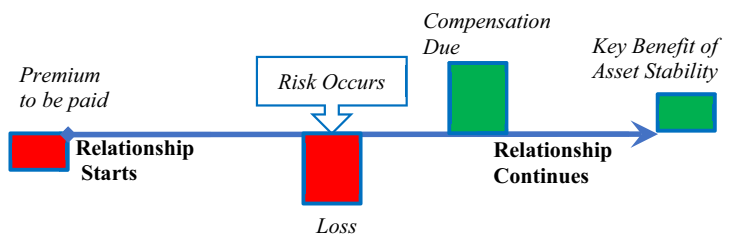

Service Perspective: Risk Does Not Occur and the Customer still Benefits

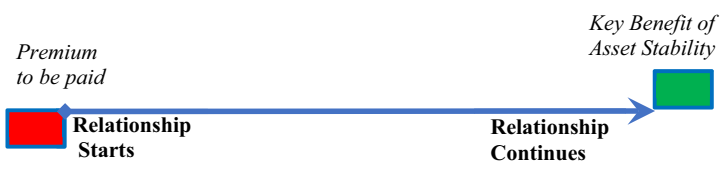

selective because the focus of analysis is broken into specific episodes. By focussing on the episode of agreement and then switching straight to the episode of compensation, they tend to "see" a gain. What is missing from this picture is the episode of the customer incurring a loss, i.e. experiencing the damage of undesired harm.

Service thinking accepts a broader view of the benefits on offer (Figure 1). Under this framework, the customer's motive is seen as the maximal avoidance of harm through attempting to maintain the full value of a focal asset at a specific level under risk exposure. In other words, the assumption is that the normality is broken by a loss incurred by the customer, which is repaired (indemnified) through the payment of compensation. Hence, there appears to be no gain at all: value is simply recovered to its original level after the expected (insured against) loss is incurred. What happens is the removal of harm, where the customer in returned to his/her original pre-agreement position after receiving the compensation. By analogy, it would be odd to argue that one made an unfair gain when one's phone was repaired under a warrant agreement. 
The goods perspective applied in Islamic legal contexts, sees insurance compensation as a gambler's payout. That is, it is understood as an unjustified gain at the expense of someone else's unfair loss (Bekkin, 2007; Al-Salih, 2004; Baltiji, 1987; Melhim, 2002). Doubts about commercial insurance being akin to gambling puzzled both classic and modern economists (Bekkin, 2007; O'Malley, 2003). What was clear is the fact that the insurance industry must be regulated with a carefully designed system of public policy to remove any doubts of market speculation (Alborn, 2007; O’Malley, 2003). According to Bekkin (2007), insurance is totally different from gambling, because:

- the gambler wilfully creates the risk, while the insurer attempts to avoid the risk;

- the gambler seeks the material gain, whereas the insurer wishes to cover the potential loss (Al-Khafif, 1966; Al-Zarqa, 1962; Siddiqi, 1985);

- the gambler might gain in wealth if he/she wins, whereas the insurer's original wealth does not change even after receiving the compensation;

- gambling produces very few winners, whereas effectively governed insurance helps all people stricken by a disaster; and

- different to the gambling context, the insurer should maintain proprietary interest in the asset that is being insured (O'Malley, 2003).

Some Muslim jurists argued that insurance definitely is different to gambling (Al-Zarqa, 1962; Siddiqi, 1985).

The service perspective does not refer to the gambling metaphor. It simply reformulates the insurance compensation as the restoration of value, i.e. indemnifying the agreed upon value of a focal asset. Gharar may not be unbalancing in such contexts, because the value of an asset is largely predetermined, while the act of restoration is a much positive function.

\section{Insurance premium}

The goods perspective sees insurance premium as a type of a gambler's bet. It assumes that the insuring parties are in fact placing a bet with a view of winning this bet (Melhim, 2002). However, the use of the gambling metaphor to conceptualise insurance is largely defective (Al-Zarqa, 1962; Bekkin, 2007; O’Malley, 2003; Siddiqi, 1985). Moreover, the insurance premium should be considered as a type of cooperative contribution that assures the ongoing provision of a useful social service (Siddiqi, 1985).

The service perspective sees insurance premium as an availability fee. It is a service fee to be paid as a compensation for the insurer's opportunity cost, i.e. tying up their resources. The availability or commitment fee is well defined in Islamic law. For some services, the occurrence of the actual service is not the requirement for the requisite payment to become due. For example, if one hires a tutor to deliver lessons or a security personnel to guard a property, the payment becomes due irrespective if one fails to attend the booked lessons in the first case or the feared threat not materialising in the second case. The principle here is that the payment is made for the commitment: the service provider commits their resources to deliver "booked" services. In the context commercial insurance, it would be grossly unfair on the insurer to argue that premiums they receive are not justified, because their resources (e.g. compensation fund, offices, personnel and IT systems) would be tied up for serving the number of customers they have.

\section{Justification of actualised benefits}

The goods perspective projects opportunism onto market actors' behaviour. In the case of commercial insurance, the total sum of premiums paid to the insurer, when the risk does not 
occur, is considered as unjustified revenue. If the risk occurs, the compensation paid to the insured is also considered as an unjustified payment. This understanding invites the presumption of riba (i.e. unjustified increase), since insurance would be seen as exchanging money for money (Bekkin, 2007). Al-Khafif (1966) showed that insurance contracts are free from riba. Siddiqi (1985) supported this argument insisting that not all incidences of "increase" should be defined as "riba". He argued that premium payments do not equal "the return of a loan", rather, they should be viewed as a contribution for the maintenance of a useful societal service. Accordingly, the riba presumption is an erroneous argument, since the service, i.e. the provision of "peace of mind" in exchange of money is an acceptable transaction (Al-Khafif, 1966; Tolefat and Asutay, 2013). Moghaizel (1991) also criticised the riba presumption arguing that premium payments represent a kind of contribution to the common pool, which guarantees uninterrupted service provision.

The service perspective emphasises the implied benefit (i.e. removal of harm by maintaining the full value of a focal asset at a specific level under risk exposure) as the essence of the transaction. This function involves resource integration by actors to serve each other, i.e. both the insurer and the insured integrate resources available to them to create a unique value for the other and themselves (Kleinaltenkamp et al., 2012; Lusch and Vargo, 2014). The delivery of insurance services requires a complex confluence, integration and coordination of diverse resources, the task that is virtually impossible for most members of society. This complex service requires substantial financial funds, specialised knowledge and skills, use of technology, offices, personnel, contact centres and communication, marketing activities, legal support, dealing with inquiries and claims, working with competitors and last but not the least, thorough compliance with government regulations. Simply the task of dealing with claims involving the customers of other insurance companies is a significant challenge in itself. The maintenance of all requisite resources kept on standby is a substantial commitment per se, which in itself justifies premiums paid to the company. Moreover, some scholars argue that the benefit the insured gets is "peace" ( $a m n)$, which is extremely valuable (Mustafa Al-Zarqa's argument, Khorshid, 2004). Paying a fee for peace of mind is not unfamiliar to Muslim jurists as the contracts of sorat (security hire) involve similar conditions.

\section{Context of commercial insurance}

From the goods perspective, commercial insurance represents a collection of individual dyads involving sellers and buyers who are assumed to be inherently opportunistic capitalising on asymmetries of the relationship. The Islamic legal perspective tends to focus on a micro picture of commercial insurance, thus deriving limiting conclusions about the nature of the exchange. The service perspective calls for shifting the attention towards the macro view of networks where the insurer as well as the customer is seen as resource integrators and inherent parts of these networks (Auda, 2008). The systems perspective focussing on the interplay between micro realities and macro worlds provides a broader picture of a commercial context (Kadirov and Varey, 2011; Kadirov, 2018). The conceptual shift from the micro view to the macro one is extremely important, as this shift allows the observers to gain a deep understanding of Islamic marketing phenomena (Kadirov, 2014). Once the observer shifts from the micro view of commercial insurance going beyond the appearance of an individual dyad, the perspectives of harm, benefit, cooperation and communal cooperation come to the fore. The broader macro perspective tends to remove the concerns of gharar (Khorshid, 2004). 


\section{Conclusion and discussion}

Scholars and practitioners must note that this paper is not a religious fatwa (ruling) on Islamic commercial insurance. Neither is it an attempt to vindicate the problematic aspects of commercial insurance as practiced in some countries nor is it a critique of modern takaful schemes. This paper offers alternative and perhaps improved, "theoretical lenses", which would help Islamic marketing scholars and practitioners to better understand the means of modes of insurance services delivery in society. Al-Qaradawi (1994) notes that Islam does not oppose the concept of insurance, it only opposes means and methods, which conflict with Islamic business principles.

To justify conventional commercial insurance, Muslim jurists franticly search for legitimate Islamic contracts, which are used as a basis of qiyas (comparison) and legitimation. Commercial insurance appears to be unique in its essence and structure. Because of this, the route of making logical comparisons may not be effective (Khorshid, 2004). Although there are some legitimated contracts such as kafalah (guarantee), sorat (security hire) or jïala (reward), which entail a high level of uncertainty (gharar), these contracts appear to be structurally different to commercial insurance. The discipline of Islamic Marketing has a potential to contribute in this space. In this paper, the author proposes another route for conceptualisation. This route rests on alternative conceptualisation: instead of looking at commercial insurance from the prism of goods thinking, scholars would be better to adopt service thinking to be able to clearly visualise the role of insurance in society and markets. Essentially, insurance should be seen as the service that unfolds over a long period of time rather than a good that requires one-off consummation.

Based on service thinking, it is argued that commercial insurance is a unique service with gradually unfolding benefits depending on unpredictable changes in the customer's circumstances. The form of commercial insurance fits the view of a long-term relationship that does not exhaust itself in a single round of sell and buy. Its key benefit is the removal of harm. In other words, it allows the customer to maintain the value of a focal asset indefinitely into the future. The compensation payout can be seen as a singular restoration of value related to a loss incurred by the customer, while premium payments can be seen as the availability fee that guarantees the concentrated dedication of the service provider's resources for this cause. There seems to be no unjustified gain in the whole relationship, because payments are done to reward the other party's ability to integrate resources to actualise expected benefits. Commercial insurance is more than a single dyad. It involves various market actors cooperating within relationship networks.

Taking a societal perspective, some scholars critique commercial insurance as a means of exploitation (Al-Fangari, 1984; Al-Qaradawi, 1994; Khorshid, 2004). Capitalising on information asymmetry, both the insurer and the customer can potentially exploit an insurance contract to their advantage. In jurisprudence, these are considered as the cases of bad faith. Because of immense market power, insurance companies are capable to manipulate the design of marketing systems so that their revenue is maximised at the expense of customers or other members of society (Kadirov et al., 2016). Hence, the negative attitude of most Muslim thinkers towards commercial insurance appears to be justified from the moral perspective. However, this seems to be an excuse for bad policy making. Islam affirms that it is the role of the government to protect market actors from each other's harm. Seeking societal benefit from a micro insurance relationship may not be logical. Rather, a macro approach should be taken (Auda, 2008; Kadirov, 2014). In particular, public policy makers should consider accepting the best global practices for regulating the insurance industry. Also, they should be equipped with service thinking,
Marketing Islamic services 
which can better elucidate a positive societal role of commercial insurance that is in accord with the societal and Islamic maxim of harm removal. It should be noted that a well-regulated commercial insurance sector can substantially contribute to the economic development of impoverished societies.

This paper also sheds light on the profound meaning of the terms such as "Islamic insurance", "halal insurance" and "takaful". The contemporary approach appears to represent a radical, "shock-therapy" kind of reform, which involves eschewing traditional models of commercial insurance, while attempting to come up with alternative "synthetic" models. These attempts seem to be analogous to "reinventing the wheel", while "throwing the baby out with the bathwater". In contrast, the service thinking approach advocates the macromarketing approach based on nurturing, fostering and development (Kadirov, 2018). This approach takes a gradual, harmonious, patience-driven and less disturbing route. Established commercial insurance practices need to be reformed, adjusted and calibrated in a gradual way through the coherent application of public policy changes. For instance, the negative practices such as investing insurance funds in riba schemes, unjustifiably refusing to cover the customer loss, manipulating the legal framework to disadvantage customers or providing bad faith information to a counterparty can be thoroughly studied and weeded out. A robust insurance market, reformed through Islam-driven public policy, governance reform, institutional change and social marketing initiatives, also represents "Islamic insurance". This form of Islamic insurance or takaful comprises reformed conventional markets, rather than models designed from scratch.

It must be noted that this article is a call to reconsider some of the mainstream conceptualisations of exchange in the domain of Islamic commerce and to re-examine misleading conclusions derived from goods thinking. Commercial insurance is the service and it must be considered as such. This paper should not be accepted as an attempt to offer a religious ruling (fatwa), since it is not within the objectives of Islamic marketing scholarship. This paper offers an alternative understanding that should enable widening the horizons of those who engage in serious contemplation of the impact of marketing practices on societal development.

\section{References}

Alborn, T. (2007), "A license to bet: life insurance and the gambling act in the British courts", Connecticut Insurance Law Journal, Vol. 14, p. 1.

Al-Fangari, M.S. (1984), Al-Islam Wal Ta’min, Ukaz Publishing, Riyadh.

Al-Khafif, A. (1966), “Al-Tamin (insurance)”, Majallat Al-Azher, Vol. 37, pp. 79-87.

Al-Natoor, B. (2019), "Why regulations, awareness and crossover can boost takaful growth", available at: https://medium.com/fitch-blog/why-regulations-awareness-and-crossover-can-boost-takafulgrowth-b2fcc2d0a86a

Al-Qaradawi, Y. (1994), The Lawful and the Prohibited in Islam (al-Halal Wal Haram Fil Islam), American Trust Publications, Plainfield, IN.

Al-Saati, A. (2003), “The permissible Gharar (risk) in classical Islamic jurisprudence”, Journal of King Abdulaziz University-Islamic Economics, Vol. 16 No. 2, pp. 3-19.

Al-Salih, M.B.A.B.S. (2004), Al-Tamin Bayan Al-Hazr Wa-al-Ibahah (Insurance between Prohibition and Acceptance), Maktabat Al-Mslik Faha Al-wtaniyah, Saudi Arabia, Al-Riyad.

Al-Zarqa, M.A. (1962), Aqd Al-Tamin (Al-Sawkarah) Wa-Mawqif Al-Sharia Al-Islamiyah Minh (Insurance Contract and the Position of Shari'ah Law from This Contract), Dimashiq, Matba 'at Jami 'at Dimshq, Syria. 
Antonio, M.S., Ali, M.M. and Akbar, N. (2013), "A comparative analysis of the efficiency of takaful and conventional insurance in Malaysia", The International Journal of Excellence in Islamic Banking and Finance, Vol. 182 No. 881, pp. 1-13.

Auda, J. (2008), Maqasid Al-Shariah as Philosophy of Islamic Law: A Systems Approach, International Institute of Islamic Thought (IIIT), Herndon, VA.

Baltiji, M. (1987), Uq'aad Al-Tamin Min Wjhat Al-Fiqh Al-Islamic (Insurance Contract from Shari'ah Law Point View), Maktabat Al-Shabab, Minera.

Bekkin, R. (2007), "Islamic insurance: national features and legal regulation", Arab Law Quarterly, Vol. 21 No. 1, pp. 3-34.

Go, S.C. (2009), Marine Insurance in The Netherlands 1600-1870: A Comparative Institutional Approach, Amsterdam University Press, Amsterdam.

Grönroos, C. (1995), "Relationship marketing: the strategy continuum", Journal of the Academy of Marketing Science, Vol. 23 No. 4, pp. 252-254.

Gummesson, E. (2011), Total Relationship Marketing, Routledge, London.

Kadirov, D. (2014), "Islamic marketing as macromarketing”, Journal of Islamic Marketing, Vol. 5 No. 1, pp. 2-19.

Kadirov, D. (2018), "Towards a theory of marketing systems as the public good", Journal of Macromarketing, Vol. 38 No. 3, pp. 278-297.

Kadirov, D. and Varey, R.J. (2011), "Symbolism in marketing systems", Journal of Macromarketing, Vol. 31 No. 2, pp. 160-171.

Kadirov, D., Varey, R.J. and Wolfenden, S. (2016), "Investigating chrematistics in marketing systems: a research framework", Journal of Macromarketing, Vol. 36 No. 1, pp. 54-67.

Kamali, M.H. (2000), Islamic Commercial Law, The Islamic Texts Society, Cambridge.

Khorshid, A. (2004), Islamic Insurance: A Modern Approach to Islamic Banking, Routledge, London.

Kingston, C. (2014), "Governance and institutional change in marine insurance, 1350-1850", European Review of Economic History, Vol. 18 No. 1, pp. 1-18.

Kleinaltenkamp, M., Brodie, R.J., Frow, P., Hughes, T., Peters, L.D. and Woratschek, H. (2012), "Resource integration", Marketing Theory, Vol. 12 No. 2, pp. 201-205.

Lusch, R.F. and Nambisan, S. (2015), "Service innovation: a service-dominant logic perspective", MIS Quarterly, Vol. 39 No. 1, pp. 155-175.

Lusch, R.F. and Vargo, S.L. (2014), The Service-Dominant Logic of Marketing: Dialog, Debate, and Directions, Routledge.

McKinsey and Company (2019), "2019 Global insurance trends and forecasts”, available at: www.mckinsey. com/industries/financial-services/our-insights/2019-global-insurance-trends-and-forecasts

Melhim, A. (2002), Al-Tamin Al-Islami (Islamic Insurance), Amman, Dar Al-A ‘alam, Jordan.

Moghaizel, F. (1991), Insurance in Light of Islamic Legal Principles, Department of Law, University of London.

Muslehuddin, M. (1966), "Insurance and Islamic law”, PhD Thesis, SOAS, University of London.

Nahar, H.S. (2015), "Insurance vs takaful: identical sides of a coin?", Journal of Financial Reporting and Accounting, Vol. 13 No. 2, pp. 247-266.

O’Malley, P. (2003), "Moral uncertainties: contract law and distinctions between speculation, gambling, and insurance", Risk and Morality, pp. 231-257.

OECD (2019), "Global insurance market trends", available at: www.oecd.org/finance/global insurancemarkettrends.htm

Sadeghi, M. (2010), "The evolution of Islamic insurance-Takaful: a literature survey", Insurance Markets and Companies: Analyses and Actuarial Computations, Vol. 1 No. 2, pp. 100-107.

Siddiqi, M.N. (1985), Insurance in an Islamic Economy, The Islamic Foundation, Leicester. 
Tolefat, A.K. and Asutay, M. (2013), Takaful Investment Portfolios: A Study of the Composition of Takaful Funds in the GCC and Malaysia, John Wiley and Sons, Singapore.

Vargo, S.L. and Lusch, R.F. (2004), "Evolving to a new dominant logic for marketing", Journal of Marketing, Vol. 68 No. 1, pp. 1-17.

Vaughan, E.J. (1996), Risk Management, Wiley, New York, NY.

Wahab, A.R.A., Lewis, M.K. and Hassan, M.K. (2007), "Islamic Takaful: business models, Shariah concerns, and proposed solutions", Thunderbird International Business Review, Vol. 49 No. 3, pp. 371-396.

Zakariyah, L. (2015), "Legal maxims in islamic criminal law: theory and applications", Series: Brill's Arab and Islamic Laws Series, Brill/Nijhoff, Vol. 9.

\section{Further reading}

Al-Mousuli, A. I M. (1284), al-Mukhtar li al-Fatawa, Baghdad.

Kadirov, D. (2015), "Marketing for society: the concept of good faith", In Annual Macromarketing Conference 2015, p. 524.

Kamali, M.H. (1991), Principles of Islamic Jurisprudence, Islamic Texts Society, Cambridge.

Wilson, R. (1984), Islamic Business: Theory and Practice, The Economist Intelligence Unit, London.

\section{Corresponding author}

Djavlonbek Kadirov can be contacted at: djavlonbek.kadirov@vuw.ac.nz

For instructions on how to order reprints of this article, please visit our website: 